\title{
Strain screening and optimization of biohydrogen production by Enterobacter aerogenes EB-06 from glycerol fermentation
}

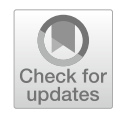

\author{
Yifeng Li, Yongqiu Qiu, Xu Zhang ${ }^{*}$, Minglong Zhu and Wensong Tan
}

\begin{abstract}
Biohydrogen technology has drawn much attention due to its many advantages. However, it is still necessary to screen much more strains with stronger hydrogen-producing capacity for future commercialization processes. In this paper, a biohydrogen-producing strain Enterobacter aerogenes EB-06 was isolated, identified, and named. It could convert glycerol to biohydrogen by microorganism fermentation. The effects of oxygen content, initial pH, initial glycerol concentration, and initial nitrogen source content on biohydrogen production process were investigated. The results have shown that biohydrogen generation was more favorable under anaerobic conditions. The optimum specific biohydrogen production rate $\left(Q_{\mathrm{H}_{2}}\right)$ was obtained as $41.47 \mathrm{mmol} \mathrm{H}_{2} / \mathrm{g}$ DCW h at $40 \mathrm{~g} / \mathrm{L}$ initial glycerol concentration. The optimum volume $\mathrm{H}_{2}$ yield $\left(\mathrm{C}_{\mathrm{H} 2}\right)$ was $83.76 \mathrm{mmol} \mathrm{H}_{2} / \mathrm{L}$ at initial $\mathrm{pH}$ 7.0. It was found that nitrogen source content $(0-4 \mathrm{~g} / \mathrm{L})$ could promote biohydrogen production and cell growth. The biohydrogen production of Enterobacter aerogenes EB-06 from glycerol was optimized by the orthogonal experimental design. The optimal yield coefficient of biohydrogen from glycerol fermentation ( $\left.Y_{\mathrm{H}_{2} / \mathrm{glycero}}\right)$ of EB-06 was obtained as $1.07 \mathrm{mmol} \mathrm{H}_{2} / \mathrm{mol}$ glycerol at $10 \mathrm{~g} / \mathrm{L}$ initial glycerol concentration, initial pH 5.0, and initial C/N ratio 5/3.
\end{abstract}

Keywords: Biohydrogen production, Condition optimization, Strain screening, Enterobacter aerogenes, Glycerol

\section{Introduction}

Hydrogen gas is a multipurpose energy source that can change the usage of hydrocarbon-based fossil fuels since the higher energy yield (122 kJ/g per unit mass), which is 2.75-fold greater than that of fossil fuels. Only water is generated as a major by-product (Asadi and Zilouei 2017; Azman et al. 2016) after hydrogen combustion. Currently, molecular hydrogen has been mainly generated from fossil fuel-based resources. Hydrogen gas production through biological pathways from biomass is one of the rising technologies due to its eco-friendly and sustainable nature (Niu et al. 2011; Sørensen 2011; Trchounian and Trchounian 2015). Dark fermentation of biohydrogen production is a promising method because of high hydrogen-producing rate, simple fermentation equipment, and bioconversion feasibility from the

\footnotetext{
*Correspondence: zhangxu@ecust.edu.cn

State Key Laboratory of Bioreactor Engineering, East China University of Science and Technology, Shanghai, China
}

recyclable resources (Dessì et al. 2018). It is essential to choose inexpensive substrates, such as glucose, xylose, glycerol, and cellulose, for the development of biohydrogen production technology (Asadi and Zilouei 2017; Pachapur et al. 2015). Recently, aviation diesel has been partly replaced by biodiesel due to the energy conservation and environmental protection (Faber and FerreiraLeitão 2016). However, a large amount of glycerol can be produced as by-product during biodiesel production process (Sivaramakrishnan and Incharoensakdi 2018). How to use these glycerol has become an urgent problem to be solved (Jitrwung and Yargeau 2011; Pott et al. 2014). The comprehensive utilization of these glycerols has been studied extensively. A wide diversity of microorganisms from environment including archaea, cyanobacteria, and bacteria (facultative aerobic and anaerobic) have been studied. Besides, lower eukaryotes are also reported as hydrogen producers, such as Thermotoga, Rhodopseudomonas palustris, Escherichia, Enterobacter aerogenes ATCC35029, Klebsiella sp. TR17 
Clostridium pasteurianum, and Chlamydomonas, which could also produce hydrogen through glycerol fermentation (Chookaew et al. 2014; Jitrwung and Yargeau 2011; Liu et al. 2015; Maru et al. 2012; Sarma et al. 2016; Zhang et al. 2015). The advantages of biohydrogen production through glycerol by microorganisms are low energy consumption, environment-friendly and high production efficiency. Ito et al. (2005) studied $\mathrm{H}_{2}$ and ethanol production through glycerol from biodiesel wastes by Enterobacter aerogenes $\mathrm{HU}-101$ fermentation. It has revealed that the optimum $Y_{\mathrm{H} 2 / \text { glycerol }}$ of pure glycerol and raw glycerol are $1.05 \mathrm{mmol} \mathrm{H}_{2} / \mathrm{mol}$ pure glycerol and $1.12 \mathrm{mmol}$ $\mathrm{H}_{2} / \mathrm{mol}$ raw glycerol, respectively. Murarka et al. (2008) investigated the mechanism of biohydrogen production process by Escherichia coli via nuclear magnetic resonance analysis of cultures. Either 50\% U-C-13-labeled or $100 \%$ unlabeled glycerol has been used. The $Y_{\mathrm{H} 2 / \text { glycerol }}$ of $0.94 \mathrm{mmol} \mathrm{H}_{2} / \mathrm{mol}$ glycerol was obtained. Selembo et al. (2010) obtained the $Y_{\mathrm{H} 2 / \text { glycerol }}$ of $0.28 \mathrm{~mol} \mathrm{H}_{2} / \mathrm{mol}$ glycerol from glycerol metabolization by heat-treated mixed bacteria. (Liu and Fang 2010) has found that the $Y_{\mathrm{H} 2 / \text { glyc- }}$ erol of $0.53 \mathrm{mmol} \mathrm{H}_{2} / \mathrm{mol}$ glycerol was obtained by Klebsiella from treated biodiesel waste.

It has certain advantages for Enterobacter aerogenes in biohydrogen production by glycerol fermentation compared with the other bacteria. For example, a large proportion of the energy in glycerol can be converted to hydrogen energy due to a relatively high $Y_{\mathrm{H} 2 / \text { glycerol }}$ obtained by Enterobacter aerogenes. Theoretically, $Y_{\mathrm{H} 2 /}$ glycerol can reach $1.00 \mathrm{~mol} \mathrm{H}_{2} / \mathrm{mol}$ glycerol. Genetic modification (Ito et al. 2005) and bacterial isolation (Mangayil et al. 2015, Poleto et al. 2016) were investigated to improve the biohydrogen production capacity. Therefore, bacteria with high biohydrogen production capacity still should be continuously screened and the key parameters of biohydrogen production through glycerol metabolism should also be optimized.

In this paper, several biohydrogen-producing strains could metabolize glycerol to produce hydrogen at high production efficiency were isolated by Hungate anaerobic rolling tube technology and identified by $16 \mathrm{~S}$ rDNA gene sequence. The effects of environmental factors, including oxygen, initial glycerol concentration, initial $\mathrm{pH}$, and initial nitrogen source concentration, on the biohydrogen production process from glycerol fermentation were investigated. And finally, the optimization of cultural condition was studied using orthogonal experiment. The results could provide technical support for the development of industrialization process of biohydrogen production.

\section{Materials and methods \\ Strain and culture \\ Strain isolation and identification}

The bacteria were isolated from river sludge of Shanghai Botanical Garden, Shanghai, China. Sludge samples were collected in the sterile test tubes and stored at $4{ }^{\circ} \mathrm{C}$. The anaerobic bacteria were enriched twice in a modified Hungate technique in combination with the sera bottle technique under anaerobic conditions at 37 ${ }^{\circ} \mathrm{C}$, which could inhibit the growth of aerobic bacteria. Bacterial morphology, physiology and biochemistry, molecular biology, and other characteristics were also investigated.

\section{Preparation of culture medium}

The batch culture medium ( $\mathrm{pH}$ 6.0-6.2) was composed of glycerol $10 \mathrm{~g} / \mathrm{L}$, peptone $4 \mathrm{~g} / \mathrm{L}$, yeast extract $2 \mathrm{~g} / \mathrm{L}, \mathrm{NaCl} 4 \mathrm{~g} / \mathrm{L}$, beef extract $4 \mathrm{~g} / \mathrm{L}, \mathrm{K}_{2} \mathrm{HPO}_{4} 1.5 \mathrm{~g} / \mathrm{L}$, $\mathrm{MgCl}_{2} 0.1 \mathrm{~g} / \mathrm{L}, \mathrm{FeSO}_{4} \cdot 7 \mathrm{H}_{2} \mathrm{O} 0.1 \mathrm{~g} / \mathrm{L}$, and trace elements $10 \mathrm{~mL}$. The medium was sterilized at $121^{\circ} \mathrm{C}$ for $20 \mathrm{~min}$. The $50 \%(\mathrm{w} / \mathrm{v})$ glycerol was sterilized at $115^{\circ} \mathrm{C}$ for $30 \mathrm{~min}$. The composition of trace elements included $\mathrm{MnSO}_{4} \cdot 7 \mathrm{H}_{2} \mathrm{O} 0.01 \mathrm{~g} / \mathrm{L}, \mathrm{ZnSO}_{4} \cdot 7 \mathrm{H}_{2} \mathrm{O} 0.05 \mathrm{~g} / \mathrm{L}, \mathrm{H}_{3} \mathrm{BO}_{3}$ $0.01 \mathrm{~g} / \mathrm{L}, \mathrm{N}\left(\mathrm{C}_{\mathrm{H} 2} \mathrm{COOH}\right)_{3} 4.5 \mathrm{~g} / \mathrm{L}, \mathrm{CaCl}_{2} \cdot 2 \mathrm{H}_{2} \mathrm{O} 0.01 \mathrm{~g} / \mathrm{L}$, $\mathrm{Na}_{2} \mathrm{MnO}_{4} 0.01 \mathrm{~g} / \mathrm{L}, \mathrm{CoCl}_{2} \cdot 6 \mathrm{H}_{2} \mathrm{O} 0.2 \mathrm{~g} / \mathrm{L}$, and $\mathrm{KAl}\left(\mathrm{SO}_{4}\right)_{2}$ $0.01 \mathrm{~g} / \mathrm{L}$.

\section{Biohydrogen production experiments}

The isolated strain was inoculated in the sterile medium and cultured in a $250 \mathrm{~mL}$ sealed flask with working volume of $100 \mathrm{~mL}$. Batch fermentations were carried out in one $500 \mathrm{~mL}$ anaerobic sera bottle with $50 \mathrm{~mL}$ of working volume by shaking at $180 \mathrm{rpm}$. The sera bottle was sealed by a rubber stopper after inoculation and flushed with $\mathrm{N}_{2}$ for $30 \mathrm{~min}$. The biogas was collected by a syringe and measured by gas chromatography immediately. The controlled $\mathrm{pH}$ was measured by a $\mathrm{pH}$ meter (FE20, Mettler-Toledo, Shanghai, PR China) at every sampling interval. All experiments were carried out in triplicate.

\section{Analytical methods Cell concentration}

The bacteria concentration was evaluated by the turbidimetric method. The optical density (OD) of cell growth was measured by a spectrophotometer $(752 \mathrm{~N}$, Shanghai Precision \& Scientific Instrument Co. Ltd., Shanghai, PR China) at $660 \mathrm{~nm}$. The DCW was calculated through the correlation between $\mathrm{OD}_{600}$ and $\mathrm{DCW}$. One $\mathrm{OD}_{660}$ unit was estimated as $0.41 \mathrm{~g} / \mathrm{L}$ dry cell weight, as shown in the following equation:

$$
1 \mathrm{OD}_{660}=0.41 \mathrm{~g} \mathrm{DCW} / \mathrm{L} \text {. }
$$




\section{Gas composition}

Gas-phase products (mainly $\mathrm{H}_{2}$ and $\mathrm{CO}_{2}$ ) were analyzed by gas chromatography (GC, 900C, Shanghai Sky Spectrum Analysis Instrument Co., Ltd., Shanghai, China). High purity nitrogen (99.999\%) was used as carrier gas. The column model was TDX-01 and the detector was TCD thermal conductivity detector. The temperatures of the chromatographic column, sampler, and detector were $80{ }^{\circ} \mathrm{C}, 100{ }^{\circ} \mathrm{C}$, and $100{ }^{\circ} \mathrm{C}$, respectively. During the test, the headspace gas of the culture bottle was sampled to analyze the composition and content. The amount of hydrogen accumulated was calculated by the percentage content of hydrogen and volume of headspace gas.

\section{Liquid-phase composition}

High-performance liquid chromatography (SHIMADZU 10A, Shimadzu International Treading Co. Ltd., Japan) was used for the analysis of composition of biohydrogen fermentation broth. The model of liquid chromatographic column was Aminex HPX-87 h. The temperature of chromatographic column was $65{ }^{\circ} \mathrm{C}$. The flow phase was $5 \mathrm{M}$ dilute sulfuric acid with the flow rate of $0.6 \mathrm{~mol} / \mathrm{min}$. The detector model was RID-10A, 8.6 Pa. The amount of sampling was $20 \mu \mathrm{L}$. The UV spectrophotometric was used to determine the glycerol concentration.

\section{Physiological and biochemical characteristics of isolates}

The bacterial physiological and biochemical characteristics were analyzed to identify the isolated strain. The extraction of bacterial genomic DNA, electrophoretic detection, PCR amplification, and the analysis of $16 \mathrm{~S}$ rDNA gene sequence were performed by Shanghai Major biological Medicine Technology Co. Ltd. The sequence was compared with the NCBI database. Sequence alignment was performed with phylogenetic analysis which was accomplished using the MEGA 6.0 software (Zhang and Sun 2008).

\section{Effect of environmental factors on biohydrogen production}

The effects of the key environmental factors, including oxygen, initial glycerol concentration, initial $\mathrm{pH}$, and initial nitrogen source content, on the biohydrogen production process through glycerol fermentation were investigated.

Orthogonal experimental design was used to examine the interaction among factors. The orthogonal experiments of three factors and three levels were conducted to investigate the effects of the interaction of factors on the bacterial growth and the biohydrogen production under the anaerobic condition. The experimental error of all data in this paper was no more than $5 \%$.

\section{Results and discussion}

Results of strains screening

For the primary isolation, 108 strains were isolated and numbered through initial enrichment, anaerobic plate culture, and anaerobic fermentation of glucose (to expand the substrate utilization range of hydrogen-producing microorganisms). It was observed that 98 strains could produce gas through the anaerobic fermentation of glucose.

For the secondary isolation, 16 strains with high biohydrogen production capacity were screened through the results of glucose fermentation from the 98 strains. The amounts of biohydrogen production of No. 6, No. 63, and No. 104 were higher than those of others. Therefore, they were selected for further investigation and named as EB-06, EB-63, and EB-104. The results of biohydrogen production of them are shown in Table 1.

It is demonstrated that the volume of biohydrogen production per milliliter of fermentation broth $\left(C_{\mathrm{H} 2}\right)$ from EB-06 was the largest in the three experimental groups. Therefore, EB-06 strain would be studied in detail as the model strain for biohydrogen production through glycerol fermentation in this paper.

\section{Identification of strain}

The bacterial morphological characteristics, physiology and biochemistry, were analyzed in this paper. It was observed that EB-06 was a facultative anaerobe, Gram-negative, rodshaped, moving, no spore, single or paired, as shown in Fig. 1. According to the results of Petri dish experiment, it was shown that the colony was milky white, neat, round, smooth, and opaque, as shown in Fig. 1a. It was pink or mauve colony on the EMB identification medium, as shown in Fig. 1b.

The results of the physiological and biochemical characteristics of EB-06, EB-104, and EB-63 are shown in Table 2. It was demonstrated that the physiological and biochemical characteristics of EB-06 were consistent with that of Enterobacter aerogenes.

The results of sequence of $16 \mathrm{~S}$ rDNA of EB-06 indicated that there were $99 \%$ homology similarity between the $16 \mathrm{~S}$ rDNA sequences of Enterobacter aerogenes LN623608,1. The phylogenetic tree of EB-06 based on 16S rDNA sequences was shown in Fig. 2. According to the physiological and biochemical characteristics, and the phylogenetic

Table 1 Partial results of the secondary screening

\begin{tabular}{llll}
\hline Strains & EB-06 & EB-104 & EB-63 \\
\hline $\mathrm{C}_{\mathrm{H} 2}\left(\mathrm{~mL} \mathrm{H} \mathrm{H}_{2} / \mathrm{mL}\right)$ & $1.00 \pm 0.001$ & $0.75 \pm 0.003$ & $0.63 \pm 0.01$ \\
\hline
\end{tabular}



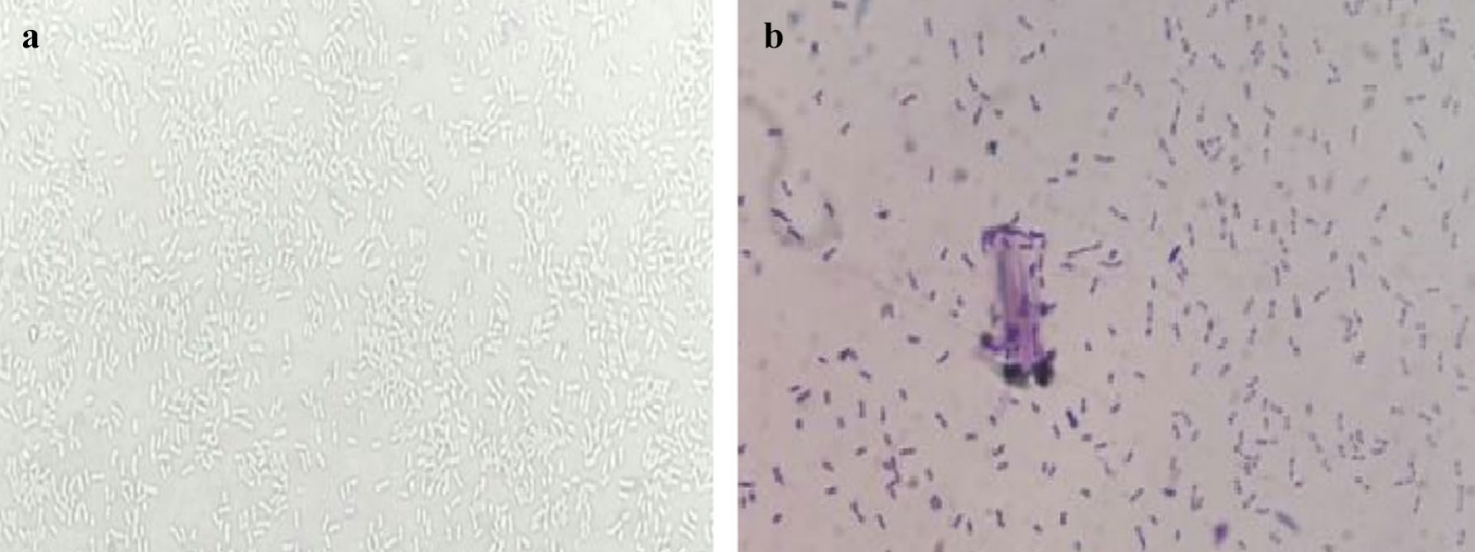

Fig. 1 Microscope picture of the EB-06 strain: a unstained bacterial morphology (10× 1000); b stained bacterial morphology $(10 \times 1000)$

Table 2 Results of the physiological and biochemical experiment of the strains

\begin{tabular}{|c|c|c|c|c|}
\hline Test name/strains & $\mathrm{EB}-06, a$ & $E B-104, \beta$ & $\mathrm{EB}-63, \gamma$ & $\begin{array}{l}\text { Enterobacter } \\
\text { aerogenes }\end{array}$ \\
\hline Catalase test & + & + & + & + \\
\hline Methyl red test & - & - & + & - \\
\hline Voges-Proskauer test & + & + & + & + \\
\hline Indole test & - & - & - & - \\
\hline Citrate utilization test & + & + & + & + \\
\hline Reduction of nitrate test & + & + & + & + \\
\hline Production of $\mathrm{H}_{2} \mathrm{~S}$ test & - & - & - & - \\
\hline Urease test & - & + & - & - \\
\hline Gelatin liquefaction test & + & + & + & + \\
\hline Glucose U & + & + & + & + \\
\hline Glycerol U & + & - & + & + \\
\hline
\end{tabular}

tree of EB-06, the target strain EB-06 was identified as Enterobacter aerogenes and named as Enterobacter aerogenes EB-06.

\section{Characteristics of biohydrogen production by Enterobacter aerogenes EB-06 through glycerol fermentation}

The Enterobacter aerogenes EB-06 strain could produce biohydrogen through glycerol fermentation. The experiment was conducted in a $500 \mathrm{~mL}$ sera bottle under anaerobic conditions at $37{ }^{\circ} \mathrm{C}, 180 \mathrm{rpm}$. The initial glycerol concentration was $10 \mathrm{~g} / \mathrm{L}$. The initial $\mathrm{pH}$ was 6.0 .

The change of amount of biohydrogen per liter of broth $\left(C_{\mathrm{H} 2}\right), \mathrm{pH}$, amount of biomass per liter of broth $\left(C_{x}\right)$, and the residual glycerol concentration $\left(C_{\text {glycerol }}\right)$ during the biohydrogen production process by EB-06 through glycerol fermentation were shown in Fig. 3. It was shown that $C_{\mathrm{H} 2}$ and $C_{x}$ in the process increased with time, while $C_{\text {glycerol }}$ decreased and $\mathrm{pH}$ maintained constantly, which means that the EB-06 strain could utilize glycerol under anaerobic conditions, accompanied by the generation of biohydrogen and acidic metabolites in the fermentation broth. In addition, the properties of biohydrogen production through glucose anaerobic fermentation by EB-06 in batch culture were also shown in Fig. 4.

It was demonstrated that EB-06 was able to utilize glycerol to produce more hydrogen and biomass than glucose from Figs. 3 and 4. Therefore, the characteristics of biohydrogen production of EB-06 by glycerol fermentation were worthy of further study. As shown in Fig. 3, it was demonstrated that $C_{\mathrm{H} 2}, \mathrm{pH}, C_{x}$, and $C_{\text {glyc- }}$ erol changed apparently from the 4th to the 8th cultural hour. After the 8th hour, the $C_{x}, \mathrm{pH}$, and $C_{\text {glycerol }}$ tended to be invariant. However, $C_{\mathrm{H} 2}$ continued to increase, which means that biohydrogen production was lagging behind the growth of EB-06 and glycerol consumption.

Figure 5 shows the trend of $\mu$ (the specific growth rate, $\mathrm{h}^{-1}$ ), $Q_{\text {glycerol }}$ (the specific rate of glycerol consumption, g/g DCW $\mathrm{h}$ ), and $Q_{\mathrm{H} 2}$ (the specific rate of hydrogen production, $\mathrm{mmol} / \mathrm{g} \mathrm{DCW}$ h) with cultural time. It was observed that the trend of $Q_{\text {glycerol }}, \mu$, and $Q_{\mathrm{H}_{2}}$ was similar during whole biohydrogen production process. All of them increased first and then decreased. The corresponding time of the maximum value of them was different.

The corresponding time of the maximum of $Q_{\mathrm{H} 2}$ significantly lagged behind those of the maximum of $Q_{\text {glycerol }}$ and $\mu$. It was indicated that the biohydrogen production was lagging behind the bacteria growth process. The corresponding time of the maximum $Q_{\text {glyc- }}$ erol appeared earlier than those of growth and biohydrogen generation. It was indicated that a large amount of glycerol was consumed in advance for the preparation 


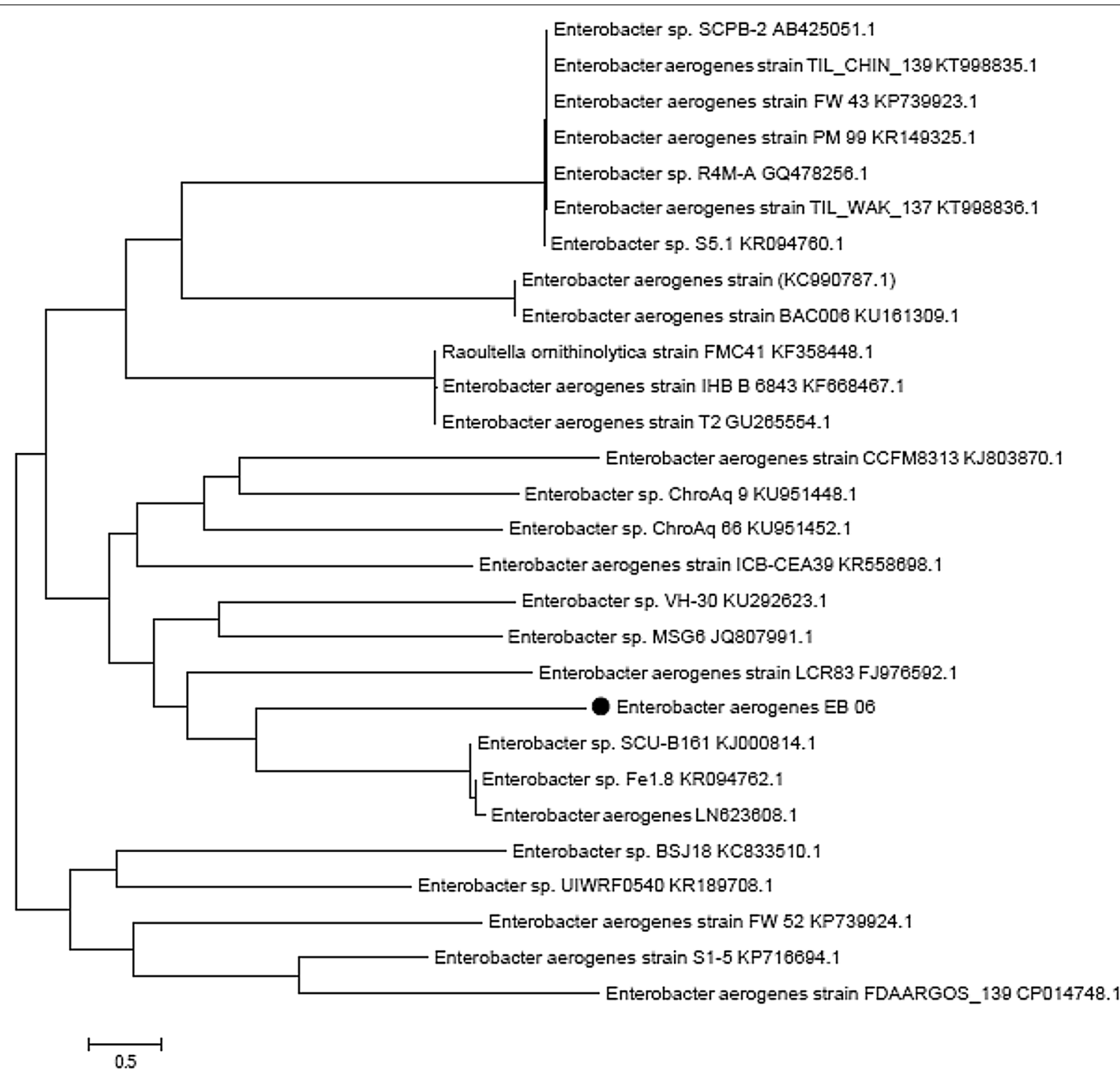

Fig. 2 The phylogenetic tree of EB-06 based on 16S rDNA sequences

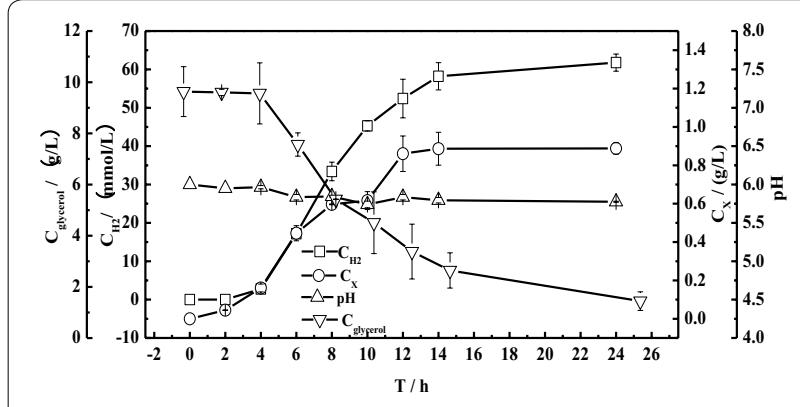

Fig. 3 The properties of biohydrogen production through glycerol anaerobic fermentation by EB-06 in batch culture

of bacterial growth and biohydrogen production during the $0-2$ nd hours of cultural time.
Effect of oxygen on biohydrogen production by EB-06 through glycerol fermentation

To study biohydrogen production characteristics of Enterobacter aerogenes under anaerobic and aerobic conditions, the effect of oxygen on the biohydrogen production by EB-06 through glycerol fermentation was explored. Figure 6 shows the change of $C_{x}$ and $C_{\mathrm{H} 2}$ with time by EB-06 through glycerol fermentation under anaerobic and aerobic conditions, respectively. It was observed that $C_{x}$ and $C_{\mathrm{H} 2}$ increased with time under both the anaerobic and aerobic conditions. The $Y_{\mathrm{H} 2 / \text { glycerol }}$ under anaerobic conditions was calculated as $0.81 \mathrm{~mol}$ $\mathrm{H}_{2} /$ mol glycerol, which was 4.5 times higher than that under aerobic conditions. 


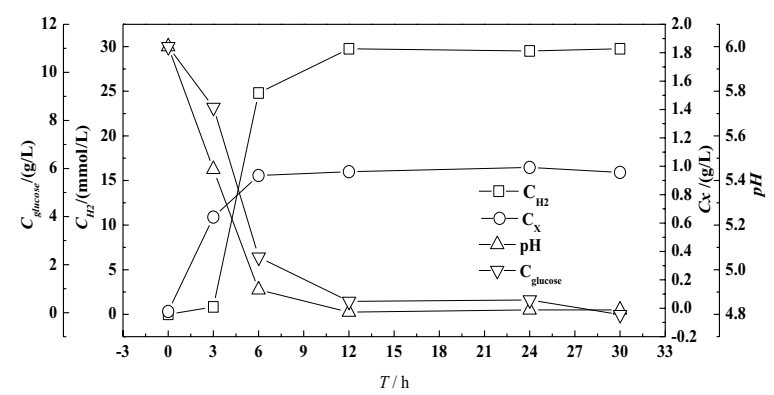

Fig. 4 The properties of biohydrogen production through glucose anaerobic fermentation by EB-06 in batch culture

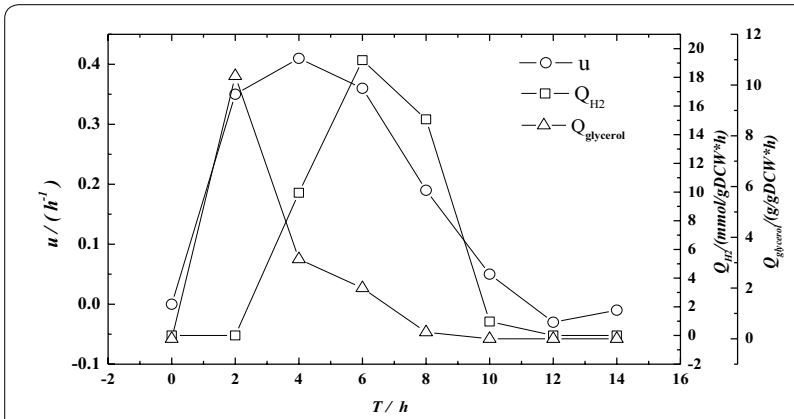

Fig. 5 The changing trend of $\mu, Q_{\text {glycerol, }}$ and $Q_{\mathrm{H} 2}$ during EB-06 biohydrogen production process

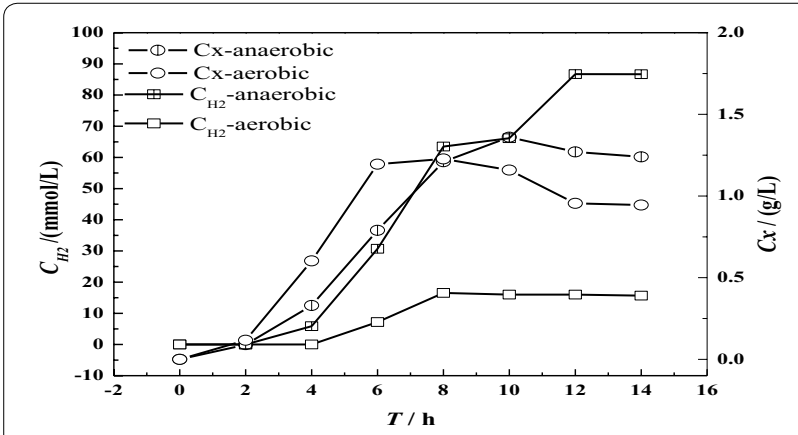

Fig. 6 Cell growth $\left(C_{x}\right)$ and hydrogen production $\left(C_{\mathrm{H}_{2}}\right)$ of EB-06 in anaerobic and aerobic fermentation

It seems that $C_{\mathrm{H} 2}$ under anaerobic conditions was much smaller than that under aerobic conditions shown in Fig. 6. It is well known that there were two biohydrogenproducing pathways in the genus of Enterobacter, i.e., formic acid hydrogen production pathway and NADH hydrogen production pathway (Kurokawa and Tanisho 2005; Leonhartsberger et al. 2002). For the former, the activity of the formate dehydrogenase could be inhibited by oxygen (Vidal-Limón et al. 2017). For the latter, NADH was converted to hydrogen through hydrogenase.
And the oxygen was used as the electron acceptor, which could efficiently provide more NADH reduction capacity and further produce more biohydrogen. Thus, the presence of oxygen will have the opposite effect on these two biohydrogen production pathways (Liu and Fang 2010). Moreover, it could also be deduced that the amount of biohydrogen produced by the formic acid pathway was different from NADH pathway. The formic acid biohydrogen production pathways might play a major role under anaerobic conditions.

On the other hand, the formate dehydrogenase activity was inhibited by $\mathrm{O}_{2}$, so that the hydrogen-producing pathway of formic acid was heavily blocked under aerobic condition (Selembo et al. 2010). Similarly, the hydrogenase could also be inhibited partly by $\mathrm{O}_{2}$. Meanwhile, $\mathrm{NADH}$ hydrogen-producing pathway was also affected. The electrons from NADH pathway could not flow to hydrogen production pathway, but to biomass (Chu et al. 2013). However, a small amount of biohydrogen was still produced under aerobic conditions, as shown in Fig. 6 . This phenomenon might due to the fact that the activities of the above two enzymes were severely inhibited in the presence of oxygen rather than being completely inactivated.

According to the results shown in Fig. 6, $C_{x}$ was $0.33 \mathrm{~g} / \mathrm{L}$ under anaerobic conditions, while it was $0.60 \mathrm{~g} / \mathrm{L}$ under aerobic conditions. It means that EB-06 could grow better under aerobic condition than that of anaerobic condition just because more NADH and ATP might be obtained for the biosynthetic pathway of EB-06 when $\mathrm{O}_{2}$ was the electron acceptor.

The trends of $\mu$ and $Q_{\mathrm{H} 2}$ during the biohydrogen production by EB-06 glycerol fermentation under aerobic and anaerobic conditions were shown in Fig. 7. It was observed that the trends of them with time were similar, whether it is under the condition of aerobic or anaerobic. All of them increased first and then decreased. It was also shown that the presence of oxygen was beneficial to the growth of EB-06, while was harmful to the biohydrogen production capacity of EB-06.

The $\mu$ and $Q_{\text {glycerol }}$ were shown in Fig. 8 during the biohydrogen production by EB-06 glycerol fermentation under aerobic and anaerobic conditions. The presence of oxygen was harmful to the consumption of glycerol by EB-06 due to the Pasteur effect.

\section{Effects of initial pH on biohydrogen production by EB-06 through glycerol fermentation}

The fermentative biohydrogen production could be effected by different initial pH (Nikhil et al. 2014). To investigate the effects of $\mathrm{pH}$ on biohydrogen production process by EB-06 through glycerol fermentation, $C_{\mathrm{H} 2}, C_{x}$, 


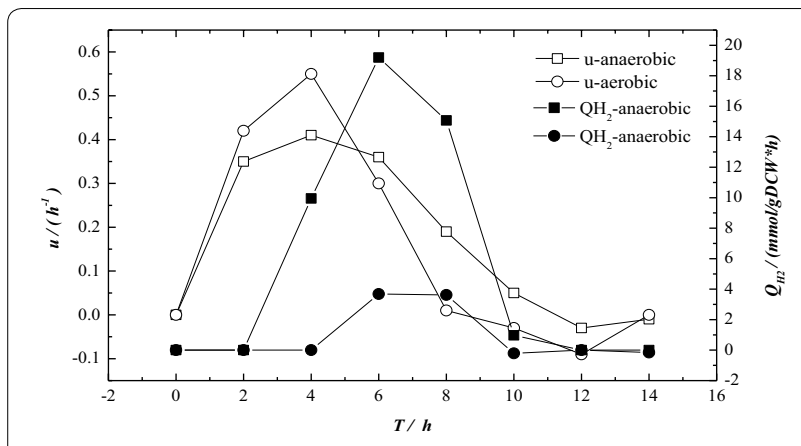

Fig. 7 The relationship with $\mu$ and $Q_{\mathrm{H}_{2}}$ during EB-06 biohydrogen production process under aerobic and anaerobic conditions

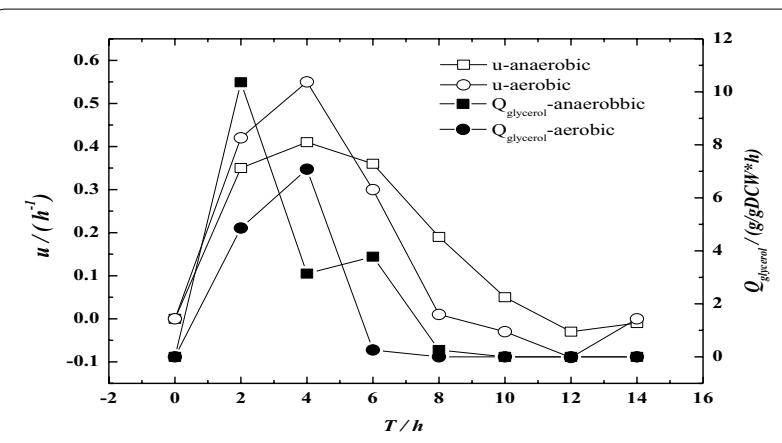

Fig. 8 The relationship with $\mu$ and $Q_{\text {glycerol }}$ observed in EB-06 biohydrogen production under aerobic and anaerobic conditions

$\mathrm{pH}$, and $C_{\text {glycerol }}$ under different initial $\mathrm{pH}$ were studied with results shown in Fig. 9.

The $C_{\mathrm{H} 2}$ under different initial $\mathrm{pH}$ are shown in Fig. 9a. It was found that $C_{\mathrm{H} 2}$ increased with time under different $\mathrm{pH}$. The $C_{\mathrm{H} 2}$ increased first and then decreased with $\mathrm{pH}$. They were significantly higher at $\mathrm{pH} 6$ and 7 than that of others. It is indicated that amount of biohydrogen generated by EB-06 would be heavily inhibited at too lower or too higher $\mathrm{pH}$. The optimum $\mathrm{C}_{\mathrm{H} 2}$ was $83.76 \mathrm{mmol} \mathrm{H}_{2} / \mathrm{L}$, and the $Y_{\mathrm{H} 2 / \text { glycerol }}$ was $0.78 \mathrm{~mol} \mathrm{H}_{2} / \mathrm{mol}$ glycerol under initial $\mathrm{pH}$ 7.0.

The effects of initial $\mathrm{pH}$ values on biomass of EB-06 were shown in Fig. 9b. It was found that $C_{x}$ in all the experimental groups increased with time, and reached to a stable stage after the 10th cultural hour. However, $C_{x}$ were first increased and then decreased with the increasing of initial $\mathrm{pH}$ values. The optimum $C_{x}$ was obtained as $1.34 \mathrm{~g} / \mathrm{L}$ at $\mathrm{pH} 6.0$.

The influence of initial $\mathrm{pH}$ on the $\mathrm{pH}$ of the fermentation broth could be seen in Fig. 9c. It was shown that the $\mathrm{pH}$ of broth had gradually decreased over time. In addition, the $\mathrm{pH}$ in the broth increased gradually with the increase of the initial $\mathrm{pH}$. It was indicated that acidic metabolites gradually produced with the glycerol/glucose fermentation progresses.

The major liquid metabolites and concentrations in biohydrogen production process from EB-06 fermentation of glucose and glycerol are shown in Table 3. It could be seen that the major liquid metabolites were lactic acid and acetic acid for glucose fermentation, while ethanol for glycerol fermentation. Therefore, the $\mathrm{pH}$ of the fermentation broth during the biohydrogen production through glycerol fermentation was more stable than those of glucose fermentation.

It was found that $C_{x}$ increased without any biohydrogen produced from 0 to 2 nd cultural hour at $\mathrm{pH} 6.0$ and 7.0 from Fig. 9. The $C_{\text {glycerol }}$ was decreased and approached zero from 8 th to 12 th cultural hour. However, $C_{\mathrm{H} 2}$ continued to increase even at the 12th cultural hour. It was reported that formic acid might be an important intermediate metabolite (Ghimire et al. 2015). Thus, to a certain extent, the amount of intracellular formic acid was likely to accumulate before hydrogen could be produced.

Another possible explanation was that there existed biohydrogen-producing step and the biohydrogenreleasing step for biohydrogen production process. The hydrogen would be released to outside of the cell when the intracellular hydrogen accumulated to a certain level (Ghimire et al. 2015).

The curves of $Q_{\mathrm{H} 2}$ with time under different initial $\mathrm{pH}$ are shown in Fig. 10. All of these $Q_{\mathrm{H} 2}$ increased first and then decreased with time. However, the maximum $Q_{\mathrm{H} 2}$ and the corresponding time under different initial $\mathrm{pH}$ were different. The optimum of $Q_{\mathrm{H} 2}$ was obtained as $22.11 \mathrm{mmol} \mathrm{H}_{2} / \mathrm{g}$ DCW $\mathrm{h}$ at initial $\mathrm{pH} 6$.

In regards to the biohydrogen production of EB-06 through glucose fermentation. The optimum $C_{x}, C_{\mathrm{H} 2}$ and $Y_{\mathrm{H} 2 / \text { glycerol }}$ was obtained as $1.42 \mathrm{~g} / \mathrm{L}, 46.13 \mathrm{mmol} \mathrm{H}_{2} / \mathrm{L}$ and $0.71 \mathrm{mmol} / \mathrm{mol}$ glycerol at initial $\mathrm{pH} 8.0$, respectively.

It could be found that the effects of the optimum initial $\mathrm{pH}$ on biohydrogen production process were different when glycerol or glucose was used as fermentation substrate. Glucose fermentation tends to occur under alkaline conditions, while glycerol fermentation tends to occur under acidic or neutral conditions.

\section{Effect of initial glycerol concentration on biohydrogen production by EB- 06 through glycerol fermentation}

The effects of different initial glycerol concentrations on biohydrogen production by EB-06 were studied by batch culture at initial $\mathrm{pH}$ 6.0. The effects of different initial glycerol concentration on $C_{\mathrm{H} 2}, C_{x}, \mathrm{pH}$, and $C_{\text {glycerol }}$ are shown in Fig. 11.

As shown in Fig. 11a, $C_{\mathrm{H} 2}$ increased gradually and eventually became invariant with time during the whole 
a

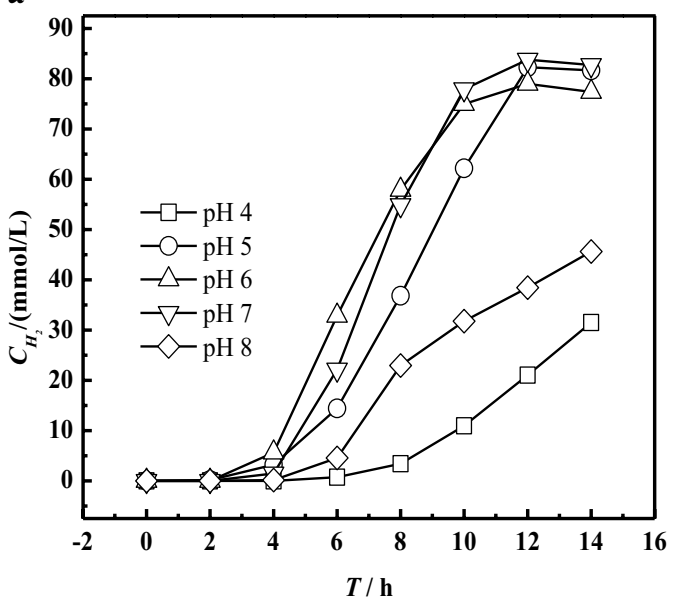

c

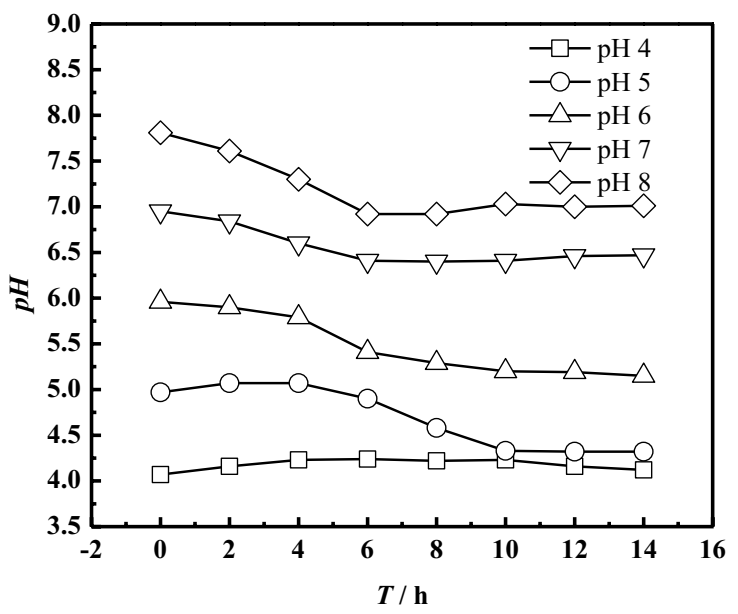

b

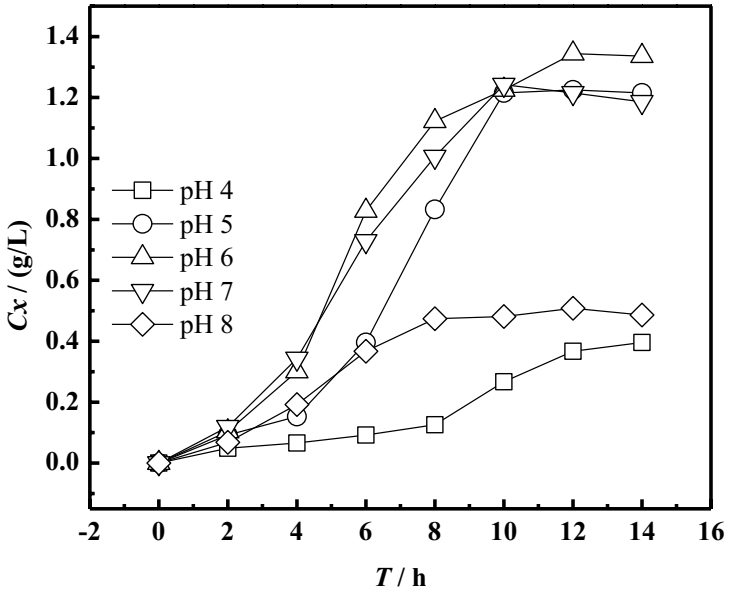

d

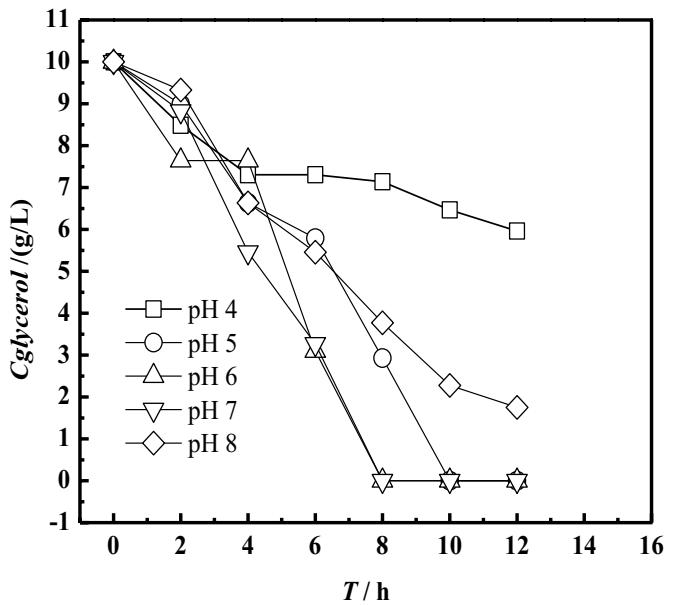

Fig. 9 The effect of different initial pH on $C_{H_{2}} \backslash C_{x} \backslash p H \backslash C_{\text {glycerol }}$ by EB-06 glycerol fermentation. $\mathbf{a} C_{H_{2}}, \mathbf{b} C_{x^{\prime}} \mathbf{c} p H$, and $\mathbf{d} C_{\text {glycerol }}$

Table 3 The major liquid products and their concentrations of biohydrogen production from EB-06 fermentation of glucose and glycerol

\begin{tabular}{llllll}
\hline $\begin{array}{l}\text { Substrate/ } \\
\text { product }\end{array}$ & $\begin{array}{l}\text { Formic } \\
\text { acid } \\
\text { (g/L) }\end{array}$ & $\begin{array}{l}\text { Acetic } \\
\text { acid } \\
\text { (g/L) }\end{array}$ & $\begin{array}{l}\text { ethanol } \\
\mathbf{( g / L )}\end{array}$ & $\begin{array}{l}\mathbf{2 , 3} \text {-butanediol } \\
\mathbf{( g / L )}\end{array}$ & $\begin{array}{l}\text { lactate } \\
\mathbf{( g / L )}\end{array}$ \\
\hline Glucose & 0.000 & 0.612 & 1.624 & A little & 0.083 \\
Glycerol & 0.000 & 0.005 & 3.873 & A little & 0.006 \\
\hline
\end{tabular}

Culture conditions: initial pH 6.0 , glycerol or glucose $(1 \%), 37^{\circ} \mathrm{C}, 180 \mathrm{rpm}$

fermentation process. However, $C_{\mathrm{H} 2}$ increased first and then decreased with initial glycerol concentration. The optimum $C_{\mathrm{H} 2}$ was obtained as $87.24 \mathrm{mmol} \mathrm{H}_{2} / \mathrm{L}$ at the initial glycerol concentration of $10 \mathrm{~g} / \mathrm{L}$. It was also reported that $C_{\mathrm{H} 2}$ would be increased with substrate concentration at the low concentration range of substrate. However, it was inhibited at high concentrations of substrate.

The cell growth curve is also shown in Fig. 11b. It was shown that the $C_{x}$ was gradually increased during whole fermentation process. However, the $C_{x}$ increased first and then decreased with the initial glycerol concentration. The growth of EB-06 was inhibited by the high initial glycerol concentrations. The optimum biomass concentration was about $1.10 \mathrm{~g} / \mathrm{L}$ at the initial glycerol concentration of $10 \mathrm{~g} / \mathrm{L}$. It was found that the Han-Levenspiel model could well describe the effect of substrate concentration on biohydrogen production.

The $\mathrm{pH}$ in the fermentation broth decreased with the fermentation time, as shown in Fig. 11c. Among them, the $\mathrm{pH}$ in the fermentation broth was decreased when the initial glycerol concentration was $10 \mathrm{~g} / \mathrm{L}$, which indicated that the amount of acidic metabolites produced were relatively large. 


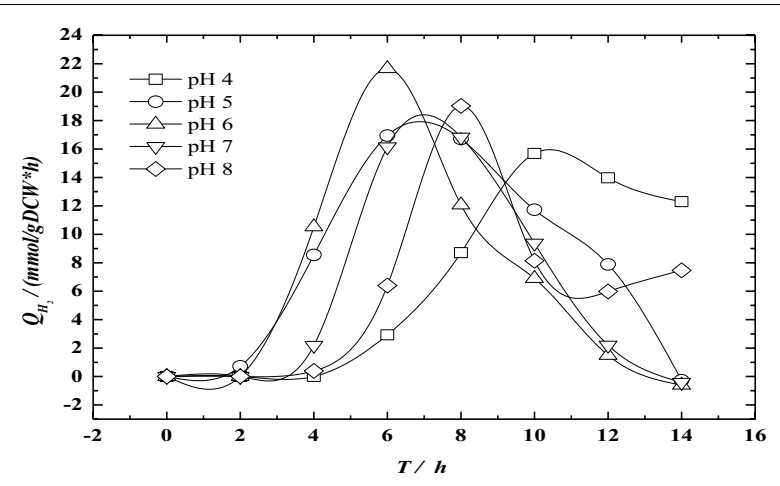

Fig. 10 The effect of different initial $\mathrm{pH}$ values on $Q_{\mathrm{H} 2}$ by EB-06 glycerol fermentation
The $C_{\text {glycerol }}$ would gradually decrease due to substrate consumption, as shown in Fig. $11 \mathrm{~d}$. The $C_{\text {glycerol }}$ increased with initial glycerol. Glycerol was completely consumed at the 8th cultural hour when the initial glycerol concentration was $5 \mathrm{~g} / \mathrm{L}$ and $10 \mathrm{~g} / \mathrm{L}$. However, glycerol had not been completely consumed at the initial glycerol concentration from 20 to $40 \mathrm{~g} / \mathrm{L}$. $Q_{\text {glycerol }}$ increased with the initial glycerol concentration. The $Q_{\text {glycerol }}$ at the initial glycerol concentration of $40 \mathrm{~g} / \mathrm{L}$ was obtained as $7.73 \mathrm{~g} / \mathrm{g}$ DCW h, as shown in Table 4. However, the total amount of glycerol consumption is less due to the lower $C_{x}$ at the higher initial concentrations of glycerol.

It was shown that the initial glycerol concentration for the optimum $C_{\mathrm{H} 2}$ was different from that of the optimum $Q_{\mathrm{H} 2}$ shown in Fig. 11a and Table 4. It was revealed that EB-06 biohydrogen production metabolism and glycerol metabolism pathway were affected by the initial glycerol concentration in Table 4. $Y_{\text {x/glycerol }}$ (yield coefficient of
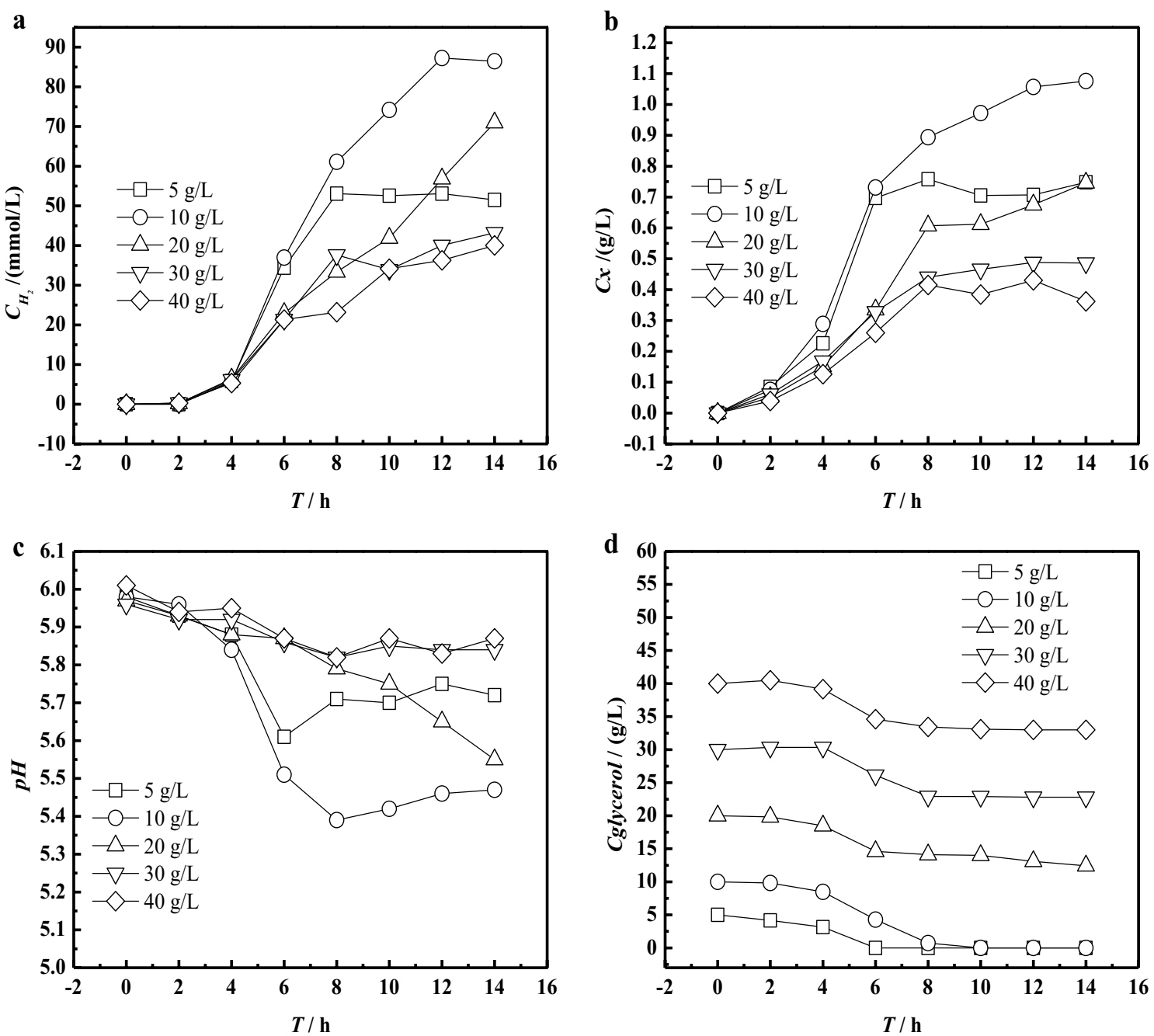

Fig. 11 The effect of different initial glycerol concentration on $\mathrm{H}_{2} \backslash \mathrm{C}_{x} \backslash \mathrm{pH} \backslash \mathrm{C}_{\text {glycerol }}$ during EB-06 glycerol fermentation: a $C_{\mathrm{H}_{2}}, \mathbf{b} \mathrm{C}_{x^{\prime}} \mathbf{c} \mathrm{pH}_{\text {, and }} \mathbf{d} \mathrm{C}_{\mathrm{glycerol}}$ 
Table 4 Parameters of biohydrogen production under different initial glycerol concentration

\begin{tabular}{lrrrrr}
\hline Glycerol concentration (g/L) & \multicolumn{1}{c}{$\mathbf{5}$} & \multicolumn{1}{c}{$\mathbf{1 0}$} & \multicolumn{1}{c}{$\mathbf{2 0}$} & \multicolumn{1}{c}{$\mathbf{3 0}$} & \multicolumn{1}{c}{$\mathbf{4 0}$} \\
\hline$Y_{\text {x/glycerol }}(\mathrm{g} / \mathrm{mol})$ & 8.40 & 6.60 & 6.00 & 5.56 & 5.26 \\
$Y_{\text {H2/glycerol }}(\mathrm{mol} \mathrm{H} / \mathrm{mol})$ & 0.99 & 0.81 & 0.77 & 0.63 & 0.56 \\
$\mathrm{Q}_{\mathrm{H} 2}\left(\mathrm{mmol} \mathrm{H}_{2} / \mathrm{g} \mathrm{DCW} \mathrm{h}\right)$ & 30.93 & 30.76 & 32.04 & 30.66 & 41.47 \\
$\mathrm{Q}_{\text {glycerol }}(\mathrm{g} / \mathrm{g} \mathrm{DCW} \mathrm{h})$ & 2.95 & 3.44 & 5.76 & 6.05 & 7.73 \\
\hline
\end{tabular}

biomass from glycerol, g/mol) and $Y_{\mathrm{H} 2 / \text { glycerol }}$ (yield coefficient of biohydrogen from glycerol consumed, mol $\mathrm{H}_{2}$ / mol) would decrease with the increasing of initial glycerol concentration, while $Q_{\mathrm{H} 2}$ and $Q_{\text {glycerol }}$ would increase with the initial glycerol concentration. The $C_{\mathrm{H} 2}$ is the integral value of the product of $Q_{\mathrm{H} 2}$ and $C_{x}$ to the fermentation time. Therefore, the optimum $C_{\mathrm{H} 2}$ was obtained when the initial glycerin concentration was $10 \mathrm{~g} / \mathrm{L}$, as shown in 11A.

The $Q_{\mathrm{H} 2}$ was related with the bacteria species and substrate type. A large number of hydrogen-producing bacteria have been isolated and screened to obtain efficient hydrogen-producing strains. (Kumar and Das 2000) isolated Enterobacter clocae IIT-BT08 from the tree leaf extract. It was found that the maximum $Q_{\mathrm{H} 2}$ was $29.63 \mathrm{mmol} \mathrm{H}_{2} / \mathrm{g}$ DCW $\mathrm{h}$ at $\mathrm{pH} 6.0$ and $37{ }^{\circ} \mathrm{C}$; the $Q_{\mathrm{H} 2}$ was from 25.0 to $28.0 \mathrm{mmol} \mathrm{H}_{2} / \mathrm{g}$ DCW h at $\mathrm{pH} 6.0$ and $36{ }^{\circ} \mathrm{C}$. (Xing et al. 2006) screened two ethanol-type hydrogen-producing bacteria Ethanoligenens harbinense sp. R3 and Ethanoligenens harbinense sp.Y3 from CSTR reactor. The maximum $Q_{\mathrm{H} 2}$ was $35.74 \mathrm{mmol} \mathrm{H}_{2} / \mathrm{g}$ $\mathrm{DCW} h$ when glucose was the substrate. It could be seen that the optimum specific hydrogen production rate would reach to $41.47 \mathrm{mmol} \mathrm{H}_{2} / \mathrm{g}$ DCW $\mathrm{h}$ when the initial glycerol concentration was $40 \mathrm{~g} / \mathrm{L}$ seen from Table 4 . It was indicated that EB-06 had a potential in biohydrogen production.

\section{Effect of initial nitrogen source on hydrogen production by EB-06 through glycerol fermentation}

It was well known that the growth and metabolism of microorganisms would be affected by the initial nitrogen source content of the medium. In this experiment, the peptone as nitrogen source contained in medium was set as $4.0 \mathrm{~g} / \mathrm{L}, 2.0 \mathrm{~g} / \mathrm{L}$, and $0.0 \mathrm{~g} / \mathrm{L}$, respectively.

Figure 12 shows that the final $C_{\mathrm{H} 2}, C_{x}$, and $Q_{\mathrm{H} 2}$ of the EB-06 biohydrogen production process under the different initial nitrogen source concentration. Moreover, both the final $C_{\mathrm{H} 2}$ and $C_{x}$ were gradually decreased with the decrease of initial nitrogen source concentration, as shown in Fig. 12a, b. The $Q_{\mathrm{H} 2}$ of EB-06 also decreased with the decrease of initial nitrogen source concentration, as shown in Fig. 12c. The results shown that initial nitrogen source played an important role in cell growth and hydrogen generation during biohydrogen production through glycerol fermentation.

\section{Optimization of biohydrogen production by EB-06 of glycerol fermentation through orthogonal design} The growth and the biohydrogen production by EB-06 through glycerol fermentation could be affected by the medium composition and environmental conditions. Orthogonal experiments can be used to optimize the interaction of multiple factors. The initial glycerol concentration, initial $\mathrm{pH}$, and initial $\mathrm{C} / \mathrm{N}$ ratio were selected as three key factors to investigate their effects on EB-06 growth and biohydrogen production according to the literature (Poleto et al. 2016). Three-factor
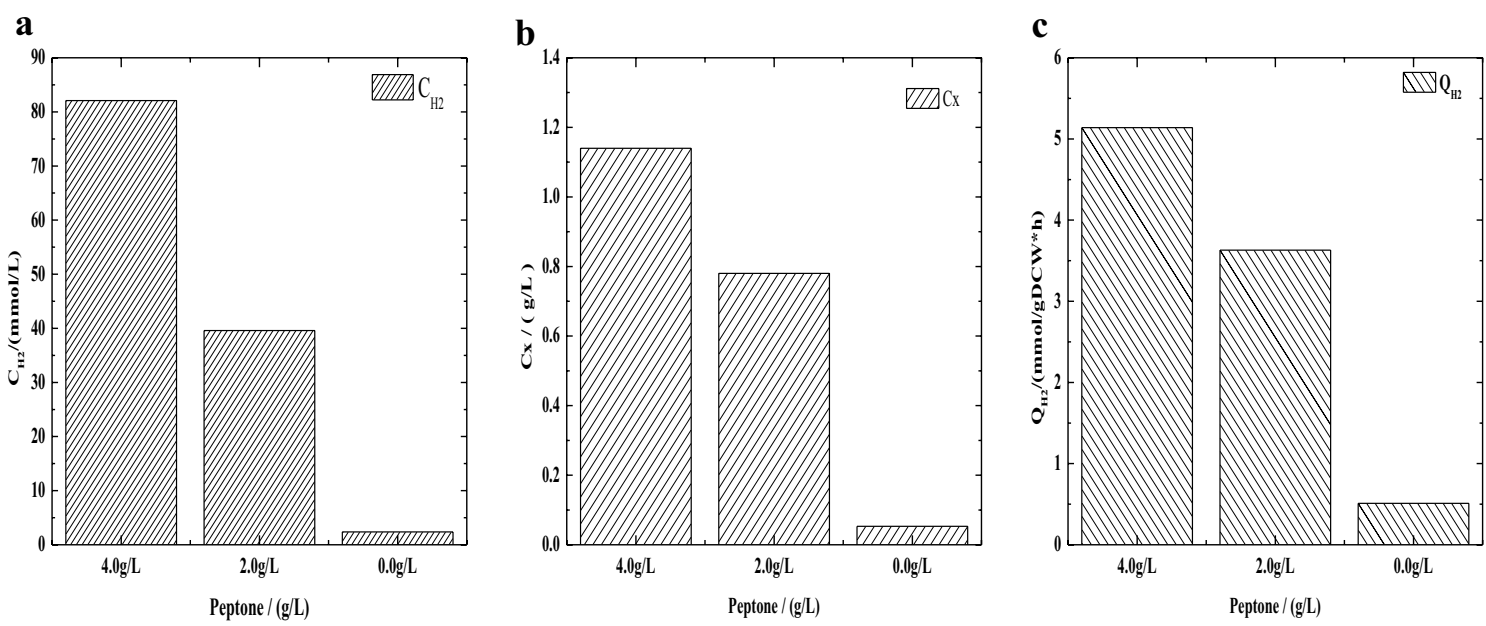

Fig. 12 The effect of nitrogen source on $C_{\mathrm{H}_{2}} \backslash C_{X} \backslash Q_{\mathrm{H}_{2}}$ by EB-06 glycerol fermentation 
Table 5 Levels of selected factors for orthogonal experimental design

\begin{tabular}{llll}
\hline Level & \multicolumn{2}{l}{ Factors } & \\
\cline { 2 - 4 } & $\boldsymbol{C}_{\text {glycerol }}(\mathbf{g} / \mathbf{L})[\mathbf{A}]$ & $\mathbf{p H}[\mathrm{B}]$ & $\mathrm{C} / \mathrm{N}$ ratio $[\mathbf{C}]$ \\
\hline 1 & 5 & 5 & $5 / 2$ \\
2 & 10 & 6 & $5 / 3$ \\
3 & 15 & 7 & $5 / 4$ \\
\hline
\end{tabular}

Table 6 The results of orthogonal test for glycerol concentration, $\mathrm{pH}$, and $\mathrm{C} / \mathrm{N}$ ratio

\begin{tabular}{lllll}
\hline $\begin{array}{l}\text { Factors/ } \\
\text { levels }\end{array}$ & $\begin{array}{l}\text { Glycerol } \\
\text { concentration } \\
(\mathbf{g} / \mathbf{L}) \\
{[\mathbf{A}]}\end{array}$ & $\begin{array}{l}\mathrm{pH} \\
{[\mathrm{B}]}\end{array}$ & $\begin{array}{l}\mathrm{C} / \mathbf{N} \text { ratio }(\mathbf{g} / \mathbf{g}) \\
{[\mathbf{C}]}\end{array}$ & $\begin{array}{l}\mathbf{Y}_{\mathbf{H 2}}\left(\mathbf{m o l ~ H}_{\mathbf{2}} \mathbf{l}\right. \\
\mathbf{m o l} \text { glycerol) }\end{array}$ \\
\hline 1 & 5 & 5 & $5 / 2$ & \\
2 & 5 & 6 & $5 / 3$ & 0.85 \\
3 & 5 & 7 & $5 / 4$ & 0.76 \\
4 & 10 & 5 & $5 / 3$ & 0.93 \\
5 & 10 & 6 & $5 / 4$ & 1.07 \\
6 & 10 & 7 & $5 / 2$ & 0.70 \\
7 & 15 & 5 & $5 / 4$ & 0.84 \\
8 & 15 & 6 & $5 / 2$ & 1.05 \\
9 & 15 & 7 & $5 / 3$ & 0.95 \\
\hline
\end{tabular}

and three-level orthogonal experiments were adopted to study the optimal medium composition and optimal culture conditions. All the orthogonal experimental design data are shown in Table 5.

The results of the orthogonal experiment are shown in Table 6. The comprehensive score was characterized by $Y_{\mathrm{H} 2}(\mathrm{~mol} / \mathrm{mol})$. It shown that the optimum $Y_{\mathrm{H} 2}$ was obtained as $1.07 \mathrm{~mol} \mathrm{H}_{2} / \mathrm{mol}$ glycerol at $10 \mathrm{~g} / \mathrm{L}$ initial glycerol, initial $\mathrm{pH} 5.0$, and initial $\mathrm{C} / \mathrm{N}$ ratio $5 / 3$.

The range analysis method was used to analyze the orthogonal experimental results of biohydrogen production through EB-06 fermented glycerol with the results shown in Table 7 . The range $R$ values of the three factors are $0.19(\mathrm{~B}), 0.17(\mathrm{~A})$, and $0.08(\mathrm{C})$, respectively. Therefore, it could be concluded that the main factor was initial $\mathrm{pH}$, followed by the initial glycerol concentration and the initial $\mathrm{C} / \mathrm{N}$ ratio.

It was shown that the optimum $Y_{\mathrm{H} 2}$ of $1.07 \mathrm{~mol} \mathrm{H}_{2} /$ mol glycerol was obtained by EB-06 in this paper. The results were close to $1.12 \mathrm{~mol} \mathrm{H}_{2} / \mathrm{mol}$ glycerol reported by (Ito et al. 2005), which was the maximum value of $Y_{\mathrm{H} 2}$ reported so far. And the yield of biohydrogen to glycerol obtained by this paper was higher than that of others shown in Table 8 .

Table 7 The results of analysis of orthogonal experimental design

\begin{tabular}{|c|c|c|c|}
\hline Calculation & $\begin{array}{l}\text { Glycerol concentration } \\
\text { (g/L) }[A]\end{array}$ & $\begin{array}{l}\mathrm{pH} \\
{[\mathrm{B}]}\end{array}$ & $\begin{array}{l}\mathrm{C} / \mathrm{N} \text { ratio }(\mathrm{g} / \mathrm{g}) \\
{[\mathrm{C}]}\end{array}$ \\
\hline K1 & 2.54 & 2.97 & 2.64 \\
\hline K2 & 2.61 & 2.41 & 2.89 \\
\hline K3 & 3.06 & 2.83 & 2.68 \\
\hline$k 1$ & 0.85 & 0.99 & 0.88 \\
\hline$k 2$ & 0.87 & 0.80 & 0.96 \\
\hline k3 & 1.02 & 0.94 & 0.89 \\
\hline $\mathrm{R}$ & 0.17 & 0.19 & 0.08 \\
\hline Primary and secondary order & $B>A>C$ & & \\
\hline Optimal levels & $\mathrm{A}_{2}$ & $\mathrm{~B}_{1}$ & $C_{2}$ \\
\hline Optimal combination & $10 \mathrm{~g} / \mathrm{L}, \mathrm{pH} 5.0, \mathrm{C} / \mathrm{N} 5 / 3$ & & \\
\hline
\end{tabular}

Table 8 Biohydrogen characteristics of some reported microorganisms from glycerol fermentation

\begin{tabular}{|c|c|c|c|c|c|c|}
\hline Substrate type & Microbial source & Reactor type & $\mathrm{T} /\left({ }^{\circ} \mathrm{C}\right)$ & $\mathrm{pH}$ & $\operatorname{Max} Y_{\mathrm{H} 2}$ & References \\
\hline Biodiesel & Enterobacter aerogenes HU-101 & Batch & $37^{\circ} \mathrm{C}$ & - & $1.12 \mathrm{~mol} \mathrm{H}_{2} / \mathrm{mol}$ glycerol & Ito et al. (2005) \\
\hline Glycerol & Enterobacter aerogenes EB-06 & Batch & $37^{\circ} \mathrm{C}$ & 6.0 & $1.07 \mathrm{~mol} \mathrm{H}_{2} / \mathrm{mol}$ glycerol & This study \\
\hline Waste glycerol & Enterobacter. aerogenes ATCC 35029 & Batch & $37^{\circ} \mathrm{C}$ & - & $0.85 \mathrm{~mol} \mathrm{H}_{2} / \mathrm{mol}$ glycerol & Jitrwung et al. (2013 \\
\hline Biodiesel-based glycerol & Enterobacter aerogenes & Batch & $37^{\circ} \mathrm{C}$ & 6.8 & $0.84 \mathrm{~mol} / \mathrm{mol}$ of glycerol & Fan et al. (2010) \\
\hline Crude glycerol & Clostridium pasteurianum & Batch & $36^{\circ} \mathrm{C}$ & 6.7 & $0.63 \mathrm{~mol} \mathrm{H}_{2} / \mathrm{mol}$ glycerol & Sarma et al. (2016) \\
\hline
\end{tabular}




\section{Conclusion}

1. A highly efficient biohydrogen-producing strain was isolated, identified, and named as Enterobacter aerogenes EB-06.

2. The characteristics of the biohydrogen production of Enterobacter aerogenes EB-06 through glycerol fermentation were analyzed in this paper. The paper also studied effects of the key environmental factors, such as oxygen, initial $\mathrm{pH}$, initial glycerol concentration, and nitrogen source on the biohydrogen production process.

3. Based on the analysis of orthogonal experiment, it was found that the main factor affecting biohydrogen production was initial $\mathrm{pH}$, followed by the initial glycerol concentration, and, finally, the initial $\mathrm{C} / \mathrm{N}$ ratio. Simultaneously, the optimum $Y_{\mathrm{H} 2}$ of $1.07 \mathrm{~mol}$ $\mathrm{H}_{2}$ /mol glycerol was obtained at the initial glycerol concentration $10.00 \mathrm{~g} / \mathrm{L}$, the initial $\mathrm{pH}$ value 5 , and the $\mathrm{C} / \mathrm{N}$ ratio $5 / 3$.

\section{Abbreviations}

$\mathrm{C}_{\mathrm{H} 2}$ : amount of hydrogen production per volume of fermentation broth $(\mathrm{mmol} / \mathrm{L}) ; C_{x}$ : cell concentration per volume of fermentation broth $(\mathrm{g} / \mathrm{L})$; $\mathrm{OD}_{6 \sigma}$ : the optical density of bacteria at $660 \mathrm{~nm}$; DCW: dry cell weight; $C_{\text {glucose: }}$ : residual glucosel concentration per volume of fermentation broth $(\mathrm{g} / \mathrm{L})$; $C_{\mathrm{glycero}}$ : residual glycerol concentration per volume of fermentation broth $(\mathrm{g} / \mathrm{L}) ; Q_{\text {glycerol }}$ : specific glycerol consumption rate [(g glycerol consumed) ( $\mathrm{g}$ dry cell formed) $\left.{ }^{-1} \mathrm{~h}^{-1}\right] ; Q_{\mathrm{H} 2}$ : specific $\mathrm{H}_{2}$ formation rate $\left[\left(\mathrm{mmol} \mathrm{H}_{2}\right.\right.$ formed) (g dry cell formed) $\left.)^{-1} \mathrm{~h}^{-1}\right] ; \mu$ : specific growth rate of biomass $\left(\mathrm{h}^{-1}\right) ; Y_{\mathrm{H} 2 / \text { glycerol }}$ : yield coefficient of $\mathrm{H}_{2}$ from glycerol $\left[\left(\mathrm{mmol} \mathrm{H}_{2} \text { formed) (g glycerol consumed }\right)^{-1}\right]$; $Y_{x / \text { glycerol }}$ :yield coefficient of biomass from glycerol [(g dry cell formed) ( $g$ glycerol consumed $)^{-1}$ ]; ATCC: American Type Culture Collection; PR: People's Republic of China; TCD: thermal conductivity detector; RID: refractive index detector; MEGA: molecular evolutionary genetic analysis; UV: ultraviolet; PCR: Polymerase Chain Reaction; NCBI: National Center for Biotechnology Information; $\mathrm{NADH}$ : nicotinamide adenine dinucleotide; ATP: adenosine triphosphate.

\section{Authors' contributions}

WT and XZ conceived and designed the experiments. YL performed the experiments and analyzed the data. YL wrote the paper. YQ helped in manuscript writing. $X Z$ and $M Z$ revised the manuscript. All authors read and approved the final manuscript.

\section{Acknowledgements}

The authors are grateful for the financial support of this research by the Open Project Funding of the State Key Laboratory of Bioreactor Engineering of China.

\section{Competing interests}

The authors declare that they have no competing interests.

\section{Availability of data and materials}

All data generated or analyzed during this study are included in the main manuscript file.

\section{Consent for publication}

The authors approved the consent for publishing the manuscript.
Ethics approval and consent to participate

Not applicable.

Funding

Not applicable.

\section{Publisher's Note}

Springer Nature remains neutral with regard to jurisdictional claims in published maps and institutional affiliations.

Received: 13 December 2018 Accepted: 19 April 2019

Published online: 02 May 2019

\section{References}

Asadi N, Zilouei H (2017) Optimization of organosolv pretreatment of rice straw for enhanced biohydrogen production using Enterobacter aerogenes. Bioresour Technol 227:335-344

Azman NF, Abdeshahian P, Kadier A, Al-Shorgani NKN, Salih NKM et al (2016) Biohydrogen production from de-oiled rice bran as sustainable feedstock in fermentative process. Int J Hydrogen Energy 41:145-156

Chookaew T, O-Thong S, Prasertsan P (2014) Biohydrogen production from crude glycerol by immobilized Klebsiella sp. TR17 in a UASB reactor and bacterial quantification under non-sterile conditions. Int J Hydrogen Energy 39:9580-9587

Chu CY, Lin T, Lin CY (2013) Effect of substrate concentration and pH on biohydrogen production kinetics from food industry wastewater by mixed culture. Int J Hydrogen Energy 38:15849-15855

Dessì P, Porca E, Waters NR, Lakaniemi AM, Collins G et al (2018) Thermophilic versus mesophilic dark fermentation in xylose-fed fluidised bed reactors: biohydrogen production and active microbial community. Int J Hydrogen Energy 43:5473-5485

Faber MO, Ferreira-Leitão VS (2016) Optimization of biohydrogen yield produced by bacterial consortia using residual glycerin from biodiesel production. Bioresour Technol 219:365-370

Fan XH, Burton R, Zhou YC (2010) Glycerol (byproduct of biodiesel production) as a source for fuels and chemicals - mini review. Open Fuels Energy Sci J $3: 17-22$

Ghimire A, Frunzo L, Pirozzi F, Trably E, Escudie R et al (2015) A review on dark fermentative biohydrogen production from organic biomass: process parameters and use of by-products. Appl Energy 144:73-95

Ito T, Nakashimada Y, Senba K, Matsui T, Nishio N (2005) Hydrogen and ethanol production from glycerol-containing wastes discharged after biodiesel manufacturing process. J Biosci Bioeng 100:260-265

Jitrwung R, Yargeau V (2011) Optimization of media composition for the production of biohydrogen from waste glycerol. Int J Hydrogen Energy 36:9602-9611

Jitrwung R, Verrett J, Yargeau V (2013) Optimization of selected salts concentration for improved biohydrogen production from biodiesel-based glycerol using Enterobacter aerogenes. Renew Energy 50:222-226

Kumar N, Das D (2000) Enhancement of hydrogen production by Enterobacter cloacae IIT-BT 08. Process Biochem 35:589-593

Kurokawa T, Tanisho S (2005) Effects of formate on fermentative hydrogen production by Enterobacter aerogenes. Mar Biotechnol 7:112-118

Leonhartsberger S, Korsa I, Böck A (2002) The molecular biology of formate metabolism in enterobacteria. J Mol Microbiol Biotechnol 4:269-276

Liu F, Fang B (2010) Optimization of bio-hydrogen production from biodiesel wastes by Klebsiella pneumoniae. Biotechnol J 2:374-380

Liu Q, Xiong DW, Hong-Bo HU, Zhang XH (2015) Hydrogen production from glycerol using a genetically engineered Escherichia coli HW2 strain. J Chem Eng Chin Univ 5:1133-1137

Mangayil R, Aho T, Karp M, Santala V (2015) Improved bioconversion of crude glycerol to hydrogen by statistical optimization of media components. Renew Energy 75:583-589

Maru BT, Bielen AAM, Kengen SWM, Constantí M, Medina F (2012) Biohydrogen production from glycerol using Thermotoga spp. Energy Procedia 29:300-307 
Murarka A, Dharmadi Y, Yazdani SS, Gonzalez R (2008) Fermentative utilization of glycerol by Escherichia coli and its implications for the production of fuels and chemicals. Appl Environ Microbiol 74:1124-1135

Nikhil GN, Mohan SV, Swamy YV (2014) Behavior of acidogenesis during biohydrogen production with formate and glucose as carbon source: substrate associated dehydrogenase expression. Int J Hydrogen Energy 39:7486-7495

Niu K, Zhang X, Tan WS, Zhu ML (2011) Effect of culture conditions on producing and uptake hydrogen flux of biohydrogen fermentation by metabolic flux analysis method. Bioresour Technol 102:7294-7300

Pachapur VL, Sarma SJ, Brar SK, Bihan YL, Buelna G et al (2015) Biohydrogen production by co-fermentation of crude glycerol and apple pomace hydrolysate using co-culture of Enterobacter aerogenes and Clostridium butyricum. Bioresour Technol 193:297-306

Poleto L, Souza P, Magrini FE, Beal LL, Torres APR et al (2016) Selection and identification of microorganisms present in the treatment of wastewater and activated sludge to produce biohydrogen from glycerol. Int J Hydrogen Energy 41:4374-4381

Pott RW, Howe CJ, Dennis JS (2014) The purification of crude glycerol derived from biodiesel manufacture and its use as a substrate by Rhodopseudomonas palustris to produce hydrogen. Bioresour Technol 152:464-470

Sarma S, Dubey VK, Moholkar VS (2016) Kinetic and thermodynamic analysis (with statistical optimization) of hydrogen production from crude glycerol using Clostridium pasteurianum. Int J Hydrogen Energy 41:19972-19989
Selembo PA, Perez JM, Lloyd WA, Logan BE (2010) Enhanced hydrogen and 1,3-propanediol production from glycerol by fermentation using mixed cultures. Biotechnol Bioeng 104:1098-1106

Sivaramakrishnan R, Incharoensakdi A (2018) Microalgae as feedstock for biodiesel production under ultrasound treatment-a review. Bioresour Technol 250:877-887

Sørensen B (2011) Hydrogen and fuel cells: emerging technologies and applications, vol 36. Academic Pr Inc, London, p 4356

Trchounian K, Trchounian A (2015) Escherichia coli hydrogen gas production from glycerol: effects of external formate. Renew Energy 83:345-351

Vidal-Limón AM, Tafoya P, Santini BL, Contreras OE, Aguila SA (2017) Electron transfer pathways analysis of oxygen tolerant [NiFe]-hydrogenases for hydrogen production: a quantum mechanics/molecular mechanics-statistical coupled analysis. Int J Hydrogen Energy 42:20494-20502

Xing D, Ren N, Li Q, Lin M, Wang A et al (2006) Ethanoligenens harbinense gen. nov., sp. nov., isolated from molasses wastewater. Int J Syst Evol Microbiol 56:755-760

Zhang W, Sun Z (2008) Random local neighbor joining: a new method for reconstructing phylogenetic trees. Mol Phylogenet Evol 47:117-128

Zhang D, Xiao N, Mahbubani KT, Rio-Chanona EAD, Slater NKH et al (2015) Bioprocess modelling of biohydrogen production by Rhodopseudomonas palustris : model development and effects of operating conditions on hydrogen yield and glycerol conversion efficiency. Chem Eng Sci 130:68-78

\section{Submit your manuscript to a SpringerOpen ${ }^{\odot}$ journal and benefit from:}

- Convenient online submission

- Rigorous peer review

- Open access: articles freely available online

- High visibility within the field

- Retaining the copyright to your article

Submit your next manuscript at $\mathbf{s p r i n g e r o p e n . c o m ~}$ 